Article

\title{
Global Changes in Urban Vegetation Cover
}

\author{
Daniel R. Richards ${ }^{1, *}$ and Richard N. Belcher ${ }^{2,3}$ \\ 1 Singapore-ETH Centre, ETH Zurich, Singapore 667968, Singapore \\ 2 Future Cities Laboratory, Singapore-ETH Centre, ETH Zurich, Singapore 667968, Singapore; \\ r.belcher19@imperial.ac.uk \\ 3 MRC Centre for Environment and Health, Department of Epidemiology and Biostatistics, St Mary's Campus, \\ Imperial College London, London W2 1PG, UK \\ * Correspondence: richards@arch.ethz.ch
}

Received: 12 November 2019; Accepted: 17 December 2019; Published: 19 December 2019

check for updates

\begin{abstract}
Urban vegetation provides many ecosystem services that make cities more liveable for people. As the world continues to urbanise, the vegetation cover in urban areas is changing rapidly. Here we use Google Earth Engine to map vegetation cover in all urban areas larger than $15 \mathrm{~km}^{2}$ in 2000 and 2015, which covered 390,000 $\mathrm{km}^{2}$ and 490,000 $\mathrm{km}^{2}$ respectively. In 2015, urban vegetation covered a substantial area, equivalent to the size of Belarus. Proportional vegetation cover was highly variable, and declined in most urban areas between 2000 and 2015. Declines in proportional vegetated cover were particularly common in the Global South. Conversely, proportional vegetation cover increased in some urban areas in eastern North America and parts of Europe. Most urban areas that increased in vegetation cover also increased in size, suggesting that the observed net increases were driven by the capture of rural ecosystems through low-density suburban sprawl. Far fewer urban areas achieved increases in vegetation cover while remaining similar in size, although this trend occurred in some regions with shrinking populations or economies. Maintaining and expanding urban vegetation cover alongside future urbanisation will be critical for the well-being of the five billion people expected to live in urban areas by 2030 .
\end{abstract}

Keywords: urbanisation; remote sensing; urban green space; sustainable development; green infrastructure

\section{Introduction}

The majority of the world's population now live in urban areas [1], making urban vegetation the type of ecosystem that most people interact with most frequently. In addition to providing opportunities for recreation [2,3], urban greenery can help to regulate urban microclimates, reduce flood risk, and support biodiversity [2,4]. These benefits are known collectively as "urban ecosystem services" [5]. The diverse ecosystem services provided by urban vegetation can make cities more comfortable places for people to live [6], improve public health $[7,8]$, and have substantial economic values [2]. The services provided by vegetation in an urban area depend on many factors, including the type of plants [9], the way that the vegetation is managed [10], and the characteristics and interests of the resident human population [11]. At the scale of the whole city, the proportional cover of vegetation is a key high-level indicator for understanding the likely ecological quality of an urban area [12-15]. Urban vegetation cover correlates with key ecosystem services such as temperature reduction [16] and the availability of green space for recreation [17]. 
Urban areas are some of the most dynamic human-modified environments on the planet. The past 30 years have seen rapid increases in the global extent of urban land [18-20], and many urban areas are projected to continue to expand in future [21,22]. During the process of urbanisation, remnant patches of natural and semi-natural vegetation are commonly built upon to support population and economic growth [17], which has led to reductions in green cover in many cities [17,23]. However, not all urban areas have experienced net losses in green cover. Some urban areas are stagnating or declining in population, economic output, and extent [24,25]. In such cities, land abandonment can provide opportunities for spontaneous vegetation growth [24]. Even in some urban areas with growing populations and economies, the increased recognition of the benefits of urban nature has led to greening initiatives to create new parks and gardens [26,27], and the construction of vegetated buildings [28].

Urban change is complex, involving interactions between economic and social drivers, governance issues, and ecological suitability — many of which are highly specific to individual urban settings [14,17]. Understanding urban change in a particular city will therefore require in-depth analysis and study, but there is also value in quantifying global variation in urban vegetation and the ecosystem services that it provides to identify more general relationships $[29,30]$. Here, we define four general trajectories of urban change by comparing changes in urban vegetation cover against changes in urban area size (Figure 1). Amongst urban areas that decline in vegetation cover, some will simultaneously increase in size as they expand into rural areas ("grey extensification"; Figure 1). This kind of urbanisation may be common in places with rapid population growth, as high demand for residential and industrial space can lead to elevated land prices, thus incentivising both inner-city densification and suburban sprawl [31,32]. Furthermore, one possible driver of grey extensification may be weaker governance structures, whereby city authorities have a limited capacity to enforce planning regulations to protect open spaces from informal settlement [33,34].

Some urban areas that decline in vegetation cover will become smaller or remain similar in size, suggesting urban densification without suburban expansion ("grey intensification"; Figure 1). Grey intensification may be expected in urban areas that experience population growth but have geographic or governance constraints that prevent suburban expansion [23]. In these areas, demand for new urban land is likely to be high, leading to densification within the urban boundary and removal of existing urban green spaces [23].

Amongst urban areas that increase in vegetation cover, some will also increase in area ("green extensification"; Figure 1). Green extensification may be driven by the capture of new vegetated areas in low-density suburbs [21], helping to increase the total vegetation cover within an urban region at the cost of expansion into peri-urban agricultural and natural land [21]. Conversely, some urban areas that increase in vegetation cover will shrink in area, or remain similar in size ("green intensification"; Figure 1). Green intensification may be common in urban areas with stagnating or declining populations, or declining economies; in these urban areas, land abandonment may lead to spontaneous vegetation growth, causing increases in vegetation cover [35]. It is also possible for urban vegetation cover to increase alongside increases in population density, if intentional urban greening is encouraged through policy and design interventions [36]. For example, urban governments may provide regulations or incentives that ensure that new urban developments result in a net increase in vegetation cover [37]. Architectural and design innovations such as smaller living spaces, high-rise accommodation, and vegetated buildings can help to simultaneously increase urban population densities while leaving more space for vegetation [38]. The drivers of trajectories of urban vegetation cover change are thus diverse, and different factors may be more or less significant in influencing the vegetated structure of cities around the world, and the way that vegetation provides urban ecosystem services [29]. 


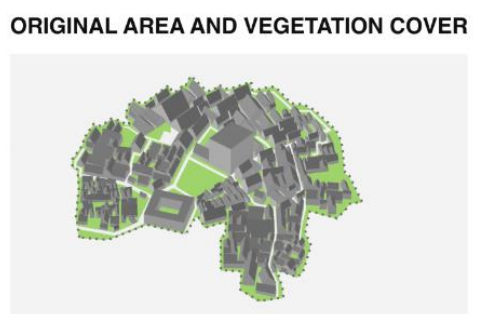

CHANGE EXAMPLES

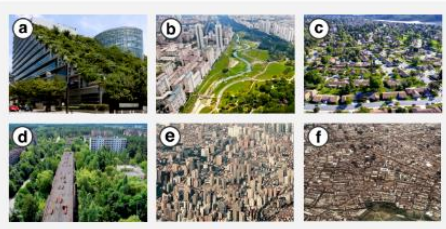

ㄴ. Urban extent $\square \quad$ Road/pavement

Building $\square$ Vegetation cove
TRAJECTORIES OF CHANGE

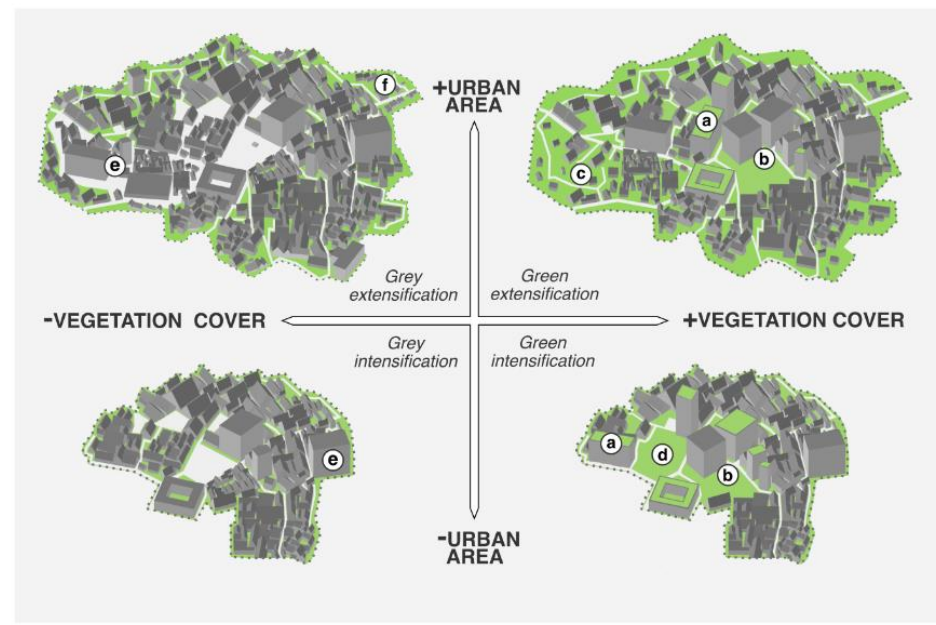

Figure 1. Urban areas can show different trajectories of change in green cover and total area over time, from those that decline in proportion of vegetation cover and simultaneously expand in area (grey extensification), decline in proportion of vegetation cover and become smaller (grey intensification), increase in vegetation cover and expand in extent (green extensification), or increase in vegetation cover and become smaller (green intensification). These macro-scale trajectories are the net result of varied local mechanisms, including (a) intentional addition of vegetation on top of buildings, (b) intentional removal of buildings to create open parks, (c) suburban sprawl creating low-density urban areas with high vegetation cover, (d) growth of spontaneous vegetation after land abandonment, (e) loss of vegetation following densification in urban cores, and (f) suburban sprawl to create high-density urban areas with low vegetation cover. Image sources given in acknowledgements section.

Despite the importance of ecosystems for the sustainability of future cities [39], we lack a global understanding of the current extent and recent rates of change in urban vegetation cover [14,15]. We conducted a global remote sensing analysis to quantify vegetation cover in all urban areas greater than $15 \mathrm{~km}^{2}$ in area in 2000 and 2015. We compared (1) the total change in proportion of vegetation cover across all urban areas that were greater than $15 \mathrm{~km}^{2}$ in size, (2) the net change in vegetation cover in urban areas that were greater than $15 \mathrm{~km}^{2}$ in size in both 2000 and 2015, and (3) the trajectories of urban change in relation to changes in size and vegetation cover.

\section{Methods}

We used a supervised remote sensing framework to classify vegetation and non-vegetation cover in all urban areas larger than $15 \mathrm{~km}^{2}$ in 2000 and 2015.

\subsection{Definition of Urban Areas Included in the Study}

The boundaries of administrative metropolitan zones are defined differently in different countries, making these boundaries unsuitable for making systematic global urban comparisons [15,40,41]. Furthermore, the size and shape of urban areas changes over time, so in order to accurately represent changes in urban vegetation cover, it is critical to use urban boundary datasets that follow consistent criteria between years. To systematically define the boundaries of urban areas in two separate years, we used the global human settlement grid layer, which mapped the global extent of built-up areas in 2000 and 2015 using Landsat imagery [42]. We used the $250 \mathrm{~m}$ resolution version of the dataset, and defined all grid cells with more than $20 \%$ of built cover as "urban", following previously-used thresholds [43]. We extracted all contiguous urban areas larger than or equal to $15 \mathrm{~km}^{2}$ in size, totalling 4929 urban areas in 2000 and 5923 in 2015. The analysis covered an area of over 390,000 km in 2000 and $490,000 \mathrm{~km}^{2}$ in 2015. Area calculations were made under the Eckert VI equal-area projection. Of the identified urban areas, 4256 were present in both 2000 and 2015. 


\subsection{Retrieval and Processing of Satellite Data}

The source satellite imagery for classification was the Landsat 7 Surface Reflectance Tier 1 image archive, providing atmospherically corrected surface reflectance at a resolution of $30 \mathrm{~m}$ by $30 \mathrm{~m}$ [44]. Cloud-free composite images were produced by processing three years of image data for each period (1999-2001 and 2014-2016) using Google Earth Engine [45]. Three years of data were used to ensure that image samples were available for each pixel to a complete composite, and we therefore assume that any changes in vegetation cover occurring within each three year period will be relatively small compared to changes occurring over the larger 2000-2015 period. Compositing was conducted on a per-pixel basis, using a temporal stack of observed values for each pixel. After extracting all images available for the study areas in these periods, all values defined as "cloud" with a confidence of "high", or as "cloud shadow" according to the CFMASK algorithm [46] were excluded from the temporal stack for each pixel. Cloud identification using CFMASK is not perfect, leaving some cirrus clouds visible. The remaining pixel values were thus composited by taking the $20^{\text {th }}$ percentile of values over the study periods for Landsat 7 bands 1-7. Median values are commonly used during similar compositing processes $[47,48]$, but the presence of cirrus cloud tends to result in a brighter pixel, so preliminary tests using the median value occasionally resulted in cirrus artefacts, particularly in tropical regions. We therefore chose to use a low percentile, following the logic of the "darkest pixel" compositing method [49]. Choosing the absolute darkest pixel available in each temporal stack would introduce the risk that darkest pixel may be an outlier caused by shadow, atmospheric conditions, or unusual temporary land cover, so we instead chose a relatively low percentile, in this case the $20^{\text {th }}$ percentile [48]. Two additional calculated bands based on the normalised difference vegetation index (NDVI) were also added for classification. NDVI is a commonly-used index of the greenness of a pixel [50], and the "greenest pixel" in a temporal stack has been previously been used in compositing [49,51]. To avoid the risk of outlier NDVI values influencing the composite [48], we extracted the $75^{\text {th }}$ percentile of NDVI over the period as an indicator of overall greenness during the growing season. We also extracted the standard deviation of NDVI over the period as an indicator of the temporal consistency or variability of vegetation [52]. The resulting stack of 9 bands was used for classification. Suitable cloud-free images were not available for all urban areas, as 8 urban areas were excluded due to lack of data in 2000, and 27 were similarly excluded in 2015.

\subsection{Training Data for Vegetation Cover Classification}

We created one training dataset for use in both 2000 and 2015, by identifying locations that did not change in land cover between these periods. Candidate training data points were generated using a stratified random approach, to sample across a range of global ecoregions and vegetation conditions. To stratify across ecoregions we classified broad ecoregion types according to the World Wildlife Fund Terrestrial Ecoregions of the World [53]. Ecoregions were grouped into four categories; tropical forest, temperate forest, grassland-dominated regions, and sparsely vegetated regions (including deserts and tundra). We sampled 250 urban areas at random from each ecoregion type. To stratify across vegetation types within each of the sampled urban areas, we calculated the normalised difference vegetation index (NDVI) in 2000 and 2014 from data provided by the Global Forest Change dataset [54]. Global Forest Change NDVI is based on Landsat 7 imagery [54] and was used because our composited Landsat 7 data were not available at the time of training data collection. To stratify across vegetation type, we sampled a maximum of 100 pixels from each of the 1000 urban areas (where enough pixels were available), randomly with stratification across decile classes of 2014 NDVI. This resulted in a candidate training sample of 78,261 points. To increase the probability of identifying training data points that did not change between 2000 and 2014, we cross-compared the NDVI values between these two years (Figure 2). Pixels that were more than 1 standard deviation from the line of equality (20,105 data points) were excluded from the potential training dataset, as a difference in NDVI indicates a likely change in land cover. 


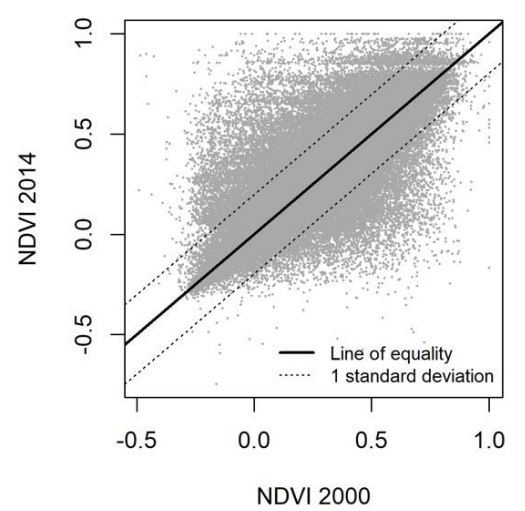

Figure 2. Comparison of Global Forest Change NDVI in 2000 and 2014, for screening of training data points to identify those deemed unlikely to have changed in green cover between the two study periods. Solid black line indicates line of equality, with dotted lines indicating 1 standard deviation from this line. Pixels within one standard deviation of the line of equality were selected as candidate training data points to increase the probability that they were unchanged in vegetation cover between 2000 and 2015.

The remaining pixel locations were viewed manually in a random order within Google Earth for classification, and were screened and classified until the required sample size of 1000 pixels was reached. True-colour aerial images of each pixel were first screened to ensure that they did not change between 2000 and 2014, using the historical image viewer in Google Earth. Next, the pixels were screened to ensure that they did not cover water. Water areas were largely absent from the training sample because the source Global Forest Change dataset excludes major water bodies and the sea [54]; only 6 water pixels were identified after screening 1,143 pixels. Finally, pixel locations that met the screening criteria were classified into either vegetated land cover or non-vegetated land cover by visual interpretation. Pixels were classified based on the dominant (> 50\%) cover.

\subsection{Supervised Vegetation Cover Classification}

We used the resulting 1000 data points (Figure 3, Table 1) to train a random forest machine learning algorithm with 10 trees per class, to classify between vegetated cover and non-vegetated cover. The random forest model classified based on the derived composite Landsat 7 satellite images bands described above, and was implemented using the ee.Classifier.randomForest function in Google Earth Engine [45]. The model accuracy was assessed by comparison with a completely random sample of 293 pixels that were viewed using the historical viewer on Google Earth (Figure 3). The overall error rate for the 2000 model was $9.2 \%$ (Table 2). The overall error rate for the 2015 model was $7.5 \%$ (Table 3).
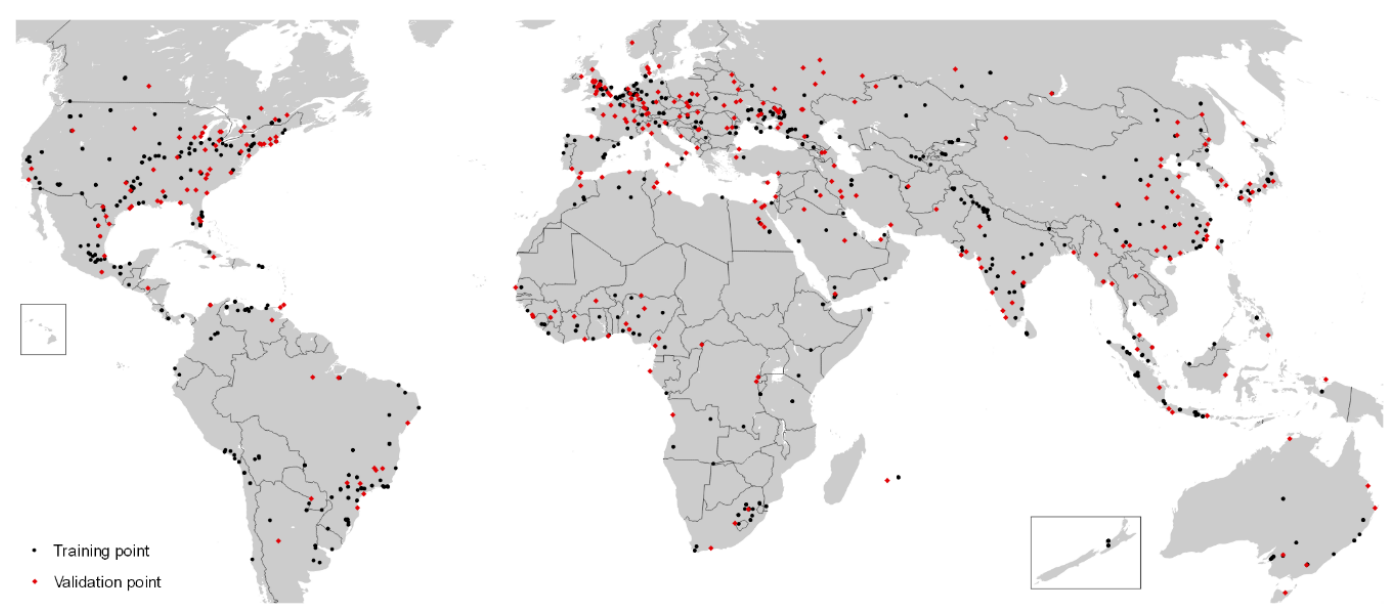

Figure 3. Training data points used for land cover classification. 
Table 1. Stratification of training pixels across broad ecoregion types and 2014 NDVI strata.

\begin{tabular}{cccccccccccc}
\hline Ecoregion Type & S1 & S2 & S3 & S4 & S5 & S6 & S7 & S8 & S9 & S10 & Totals \\
\hline Tropical forests & 30 & 25 & 20 & 17 & 30 & 19 & 29 & 16 & 24 & 21 & 231 \\
Temperate forests & 40 & 49 & 28 & 28 & 20 & 30 & 30 & 30 & 36 & 36 & 327 \\
Grasslands & 37 & 33 & 21 & 28 & 29 & 23 & 29 & 17 & 12 & 14 & 243 \\
Unvegetated & 45 & 31 & 26 & 16 & 22 & 11 & 12 & 14 & 7 & 15 & 199 \\
Totals & 152 & 138 & 95 & 89 & 101 & 83 & 100 & 77 & 79 & 86 & 1000 \\
\hline
\end{tabular}

Table 2. Confusion matrix for classification model of green space cover and unvegetated cover in 2000. Comparison between random forest predictions and 293 novel validation points.

\begin{tabular}{cccc}
\hline & Vegetated Cover & Unvegetated Cover & Error \\
\hline Vegetated cover & 161 & 15 & 0.10 \\
Unvegetated cover & 12 & 105 & 0.09 \\
\hline
\end{tabular}

Table 3. Confusion matrix for the classification model of green space cover and unvegetated cover in 2015. Comparison between random forest predictions and 293 novel validation points.

\begin{tabular}{cccc}
\hline & Vegetated Cover & Unvegetated Cover & Error \\
\hline Vegetated cover & 174 & 14 & 0.08 \\
Unvegetated cover & 8 & 97 & 0.07 \\
\hline
\end{tabular}

\subsection{Vegetation Cover Classification Uncertainty Analysis and Bootstrap Simulation for Significance Testing}

We quantified vegetation cover in each urban area by extracting vegetation and non-vegetation pixels from the land area analysed by Global Forest Change [54]. We calculated error-corrected estimates of the vegetation cover in each urban area in 2000 and 2015 using the class-specific errors given in the confusion matrices (Tables 2 and 3) [55]. To assess whether individual cities significantly increased or decreased in their proportion of vegetation cover between 2000 and 2015, we used a bootstrap simulation to carry forward the uncertainty in land cover classification. Within an urban area, the random forest models classified all pixels as either vegetation cover or non-vegetation cover. For each pixel, we estimated the probability of actual vegetation cover, based on the class-specific error rates obtained from the confusion matrices (Tables 2 and 3). For pixels classified as vegetation, the probability that they were vegetation was defined as:

$$
P(G)=1-E_{G}
$$

where $P(G)$ is the probability of the pixel being vegetation and $E_{G}$ is the error estimate for the vegetation cover class. For pixels classified as non-vegetation, the probability that they were vegetation was defined as;

$$
P(G)=E_{N}
$$

where $E_{N}$ was the error estimate for the non-green cover class. For each of 1000 bootstrap replicates, we applied these probabilities to the number of pixels that were green and non-green according to the classification, to simulate 1000 bootstrap alternatives of urban vegetation cover in 2000 and 2015 . We then calculated the change in proportional vegetation cover as the proportion of vegetation cover in 2015 - the proportion of vegetation cover in 2000.

To assess the significance of change in the proportion of vegetation cover in each urban area between 2000 and 2015, we took the 2.5th and 97.5th percentile of the differences between the 1000 bootstrap simulations as the $95 \%$ confidence intervals for the change [56]. We defined a significant change in vegetation cover if these $95 \%$ confidence intervals did not overlap zero. Urban areas were considered to have been present in both 2000 and 2015 if the extents from these two periods overlapped in any way. In cases where multiple urban areas from one period overlapped with one urban area from 
the other period, the proportional vegetation cover was calculated as the total across all overlapping urban areas.

\subsection{Statistical Analysis of Difference in Global Urban Vegetation Cover}

We analysed the difference in vegetation cover across all studied urban areas between 2000 and 2015 using a binomial mixed-effects generalised linear model [57]. Urban areas that were present in both 2000 and 2015 were paired using a random effect, and an additional random effect was included to account for potential variation caused by differing cultural and political situations in different countries. The country of each urban area was taken to be the country that the majority of the urban area was located in. To assess the robustness of conclusions with respect to the errors in vegetation cover classification described above, we used 1000 simulated alternatives of urban vegetation cover to bootstrap the regression model. The $95 \%$ confidence intervals for the model coefficients and p values were extracted as the 2.5th percentile and 97.5th percentile of all bootstrapped values [56].

\subsection{National-Scale Comparison}

We took the median vegetation cover change values, and median size change values, from the urban areas located in each territory. Territories were excluded from the analysis if they contained less than 10 urban areas.

\subsection{Urban Change Trajectories}

For all 4256 urban areas present in both 2000 and 2015, we compared the trajectory of change by plotting the change in percentage vegetation cover against the change in size of the urban area over the study period. Change in size was calculated as a percentage of the land area in 2000. To assign a trajectory, we first assessed whether the urban area had increased or decreased in size and lost or gained vegetation cover (Figure 1). However, a substantial number of urban areas did not change much in size, so could be considered to have increased or decreased in vegetation cover while remaining "similar" in size. To assess the sensitivity of the findings to the definition of "similar in size", we counted the number of urban areas following each trajectory type when using thresholds of $0 \%, 1 \%$, and $5 \%$ increases in area.

\section{Results}

We mapped $176,000 \mathrm{~km}^{2}$ of urban vegetation cover in 2000 and $210,000 \mathrm{~km}^{2}$ in 2015 . The total area of urban vegetation has thus increased rapidly, at a rate of more than $1 \%$ of the 2000 extent every year. This corresponds to the widespread expansion of urban areas, as more than $100,000 \mathrm{~km}^{2}$ of additional urban area was analysed in 2015 than in 2000. The percentage vegetation cover in urban areas has significantly declined, from a median of $47 \%$ in 2000 , to a median of $42 \%$ in $2015(z=-745.1, p<0.001$; Tables 4 and 5). Of the 4256 urban areas analysed in both years, 2,307 urban areas declined significantly in vegetation cover. Declines in urban vegetation cover were observed in rapidly developing countries in Africa, Asia, and South America (Figure 4), with median reductions of more than 15\% in Nigeria and Vietnam (Table 6). In Europe, vegetation cover declined in the United Kingdom (UK) (Table 6) as well as in Switzerland, western Germany, and Russia (Figure 4). Despite the overall reduction in vegetation cover, 1,786 urban areas increased significantly in vegetation cover over the study period. Increases in vegetation cover occurred mainly in parts of Europe and eastern North America (Figure 4), with Hungary and Greece showing the largest median increases of greater than 10\% (Table 6). 
Table 4. Fixed effects from binomial generalised linear model of the differences between proportional green cover in 2000 and 2015. Lower and upper 95\% confidence intervals were derived from 1000 bootstrap replicates. The bootstrap $p$ is the 97.5 th percentile of the $p$-values from the 1000 bootstrap replicates.

\begin{tabular}{cccccccc}
\hline Variable & Coefficient & Std. Error & $\begin{array}{c}\text { Lower CI } \\
\mathbf{( 2 . 5 \% )}\end{array}$ & $\begin{array}{c}\text { Upper CI } \\
\mathbf{( 9 7 . 5 \% )}\end{array}$ & $\mathbf{z}$ & $\boldsymbol{p}$ & Bootstrap $\boldsymbol{p}$ \\
\hline Intercept & -0.20 & 0.06 & -0.20 & -0.19 & -3.5 & $<0.001$ & $<0.001$ \\
Year 2015 & -0.14 & $<0.01$ & -0.14 & -0.14 & -713.1 & $<0.001$ & $<0.001$ \\
\hline
\end{tabular}

Table 5. Random effects from binomial generalised linear model of the differences between proportional green cover in 2000 and 2015.

\begin{tabular}{ccc}
\hline Variable & Variance & Std. Deviation \\
\hline Urban area & 0.77 & 0.88 \\
Country & 0.47 & 0.68 \\
\hline
\end{tabular}
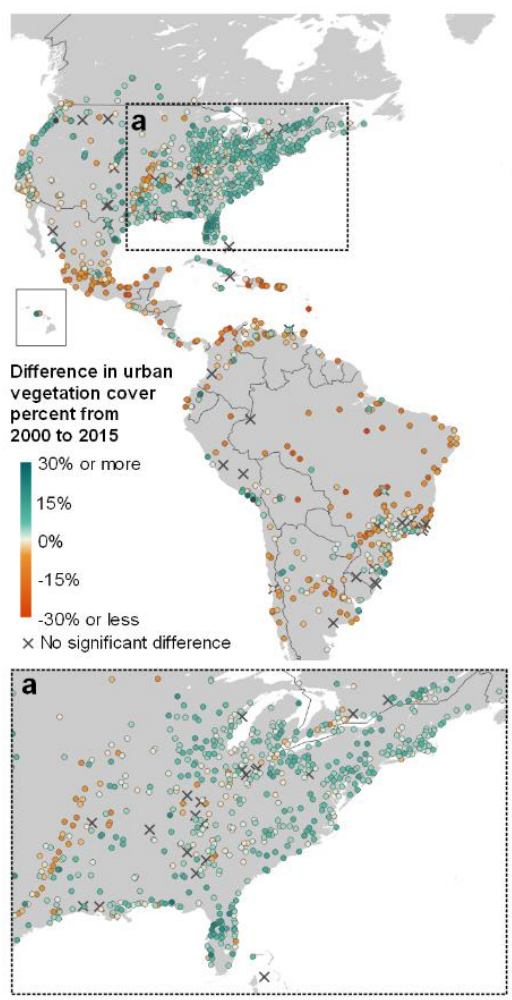
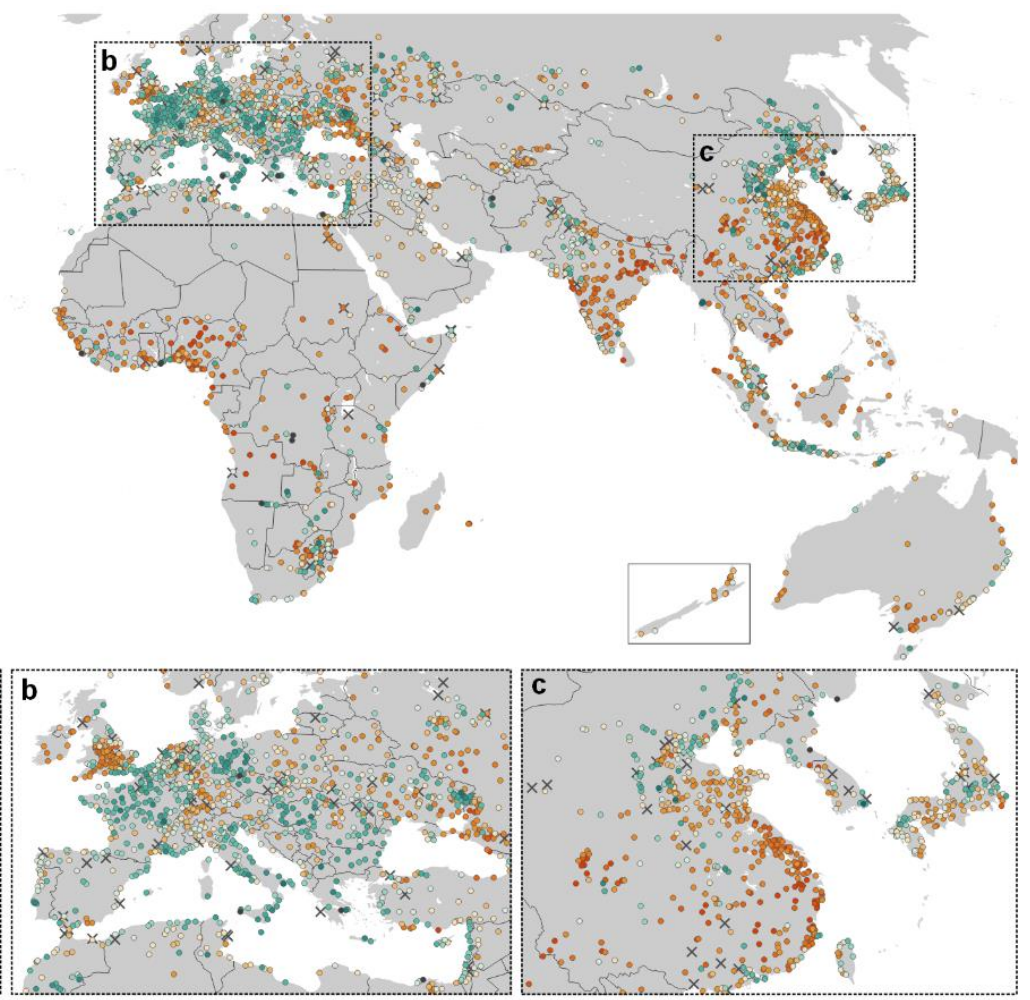

Figure 4. Net difference in vegetation cover percentage between 2000 and 2015, in all urban areas larger than $15 \mathrm{~km}^{2}$ that existed in both these years. Inset subfigures show more detail for regions with large numbers of urban areas; (a) eastern North America, (b) Europe, and (c) East Asia. Significant vegetation cover change shown for 4,093 urban areas and no significant change shown for 163 urban areas.

Over half of the 4,256 urban areas both decreased in vegetation cover and increased in area, showing a trajectory of grey extensification (Figure 5; Table 7). Among the countries that showed the greatest declines in urban vegetation cover, many showed substantial increases in urban extent; for example, urban areas in Nigeria grew in size by a median of 50\% (Table 6). Few urban areas showed a trajectory of grey intensification (Figure 5; Table 7). For urban areas that increased in vegetation cover, the majority increased in size, thus showing a trajectory of green extensification (Figure 5; Table 7). Some of the countries with the highest median increases in urban vegetation cover, such as Hungary, Czechia, Romania, USA, and Canada, also showed median increases in size of greater than $10 \%$ (Table 6). The least common trajectory was green intensification, as few urban areas simultaneously 
decreased in size and increased in vegetation cover (Figure 5; Table 7). However, a slightly larger number of urban areas increased in vegetation cover while remaining approximately similar in size, depending on the threshold of change in size that was chosen (Table 7).

Table 6. The 10 countries with the largest decreases and increases in the median proportion of urban vegetation cover. Only countries with more than 10 urban areas are included.

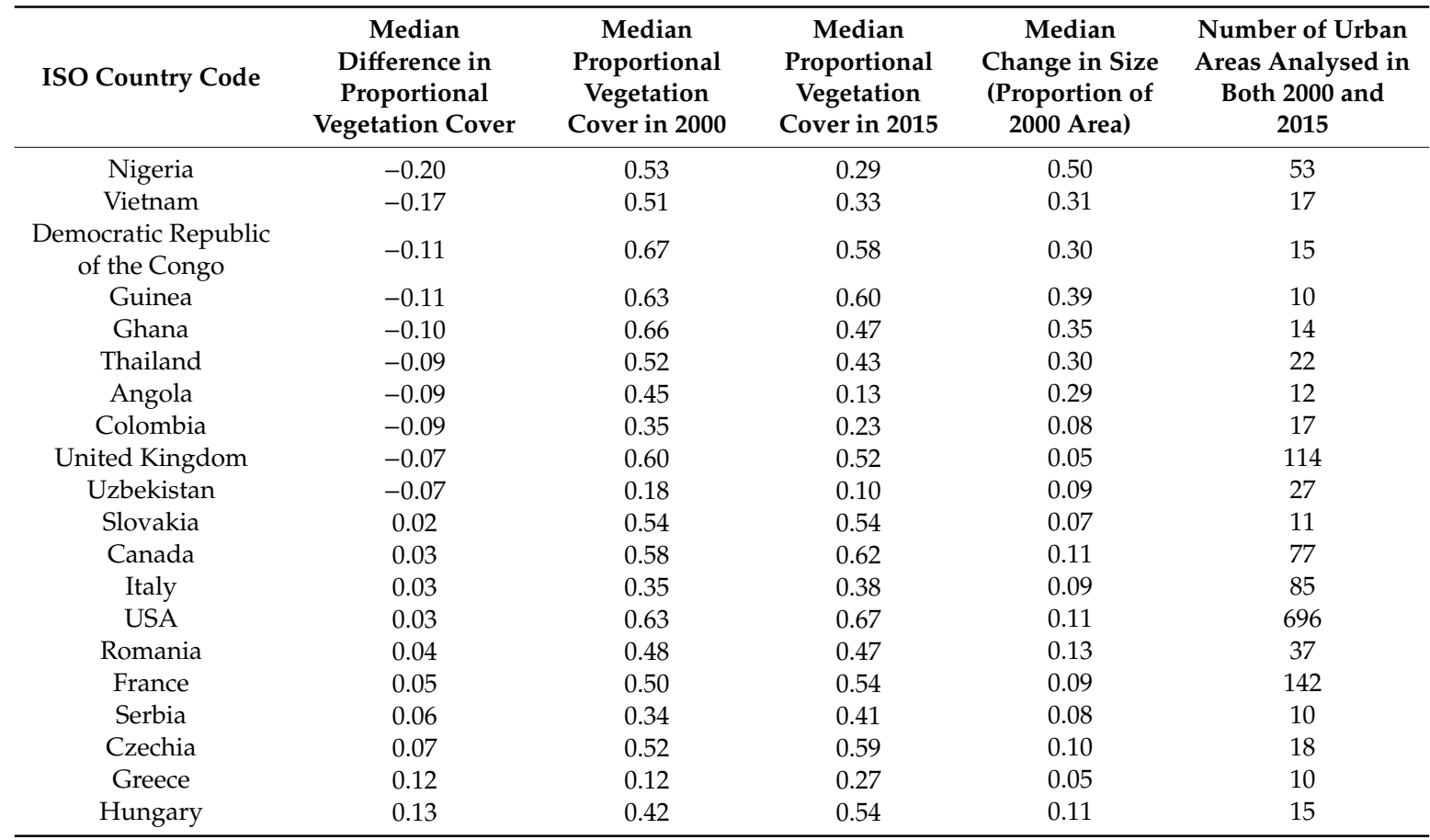

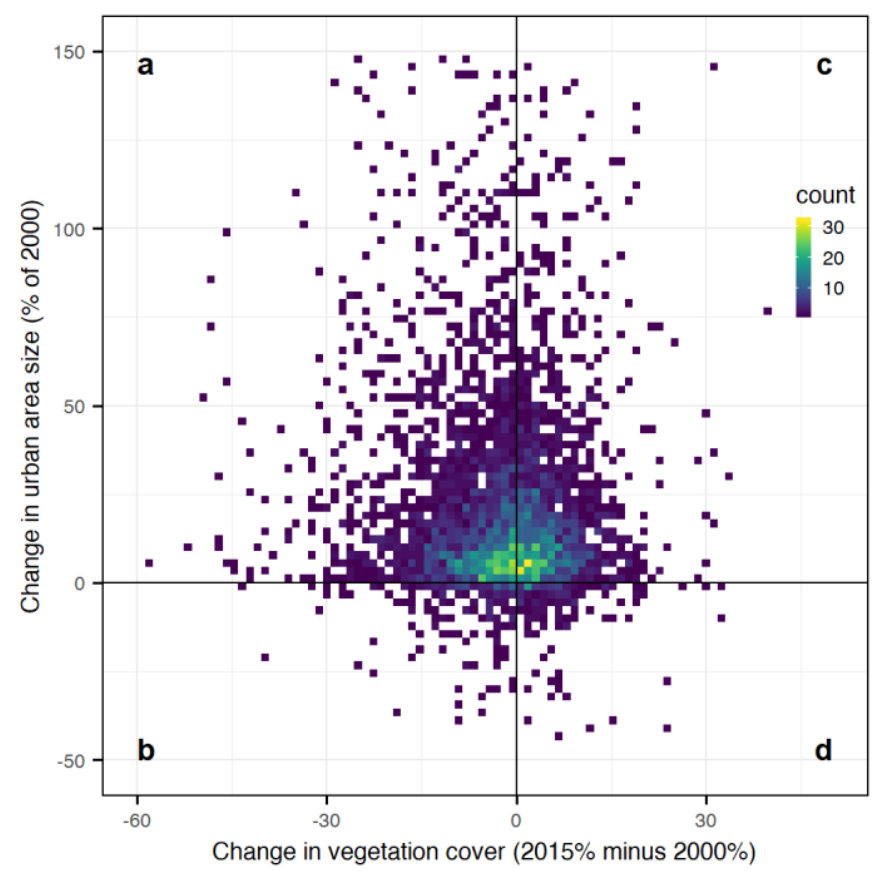

Figure 5. Change in urban areas according rates of change in the total urban area, and difference in percentage vegetation cover, between 2000 and 2015. These axes highlight urban areas that show trajectories of (a) grey extensification, (b) grey intensification, (c) green extensification, and (d) green intensification. Urban areas with changes in area of more than $150 \%$ or less than $-50 \%$ (totalling 127 urban areas) are not shown. 
Table 7. Sensitivity of urban change trajectory categorisation to the threshold of increase in urban area size that is used. Under the $1 \%$ and $5 \%$ increase thresholds, urban areas falling below this threshold are considered to have remained similar in size.

\begin{tabular}{|c|c|c|c|}
\hline \multirow[t]{2}{*}{ Trajectory } & \multicolumn{3}{|c|}{ Number of Urban Areas under Different Size Change Thresholds } \\
\hline & $\begin{array}{c}0 \% \text { Size Increase } \\
\text { Threshold }\end{array}$ & $\begin{array}{c}\text { 1\% Size Increase } \\
\text { Threshold }\end{array}$ & $\begin{array}{c}5 \% \text { Size Increase } \\
\text { Threshold }\end{array}$ \\
\hline Grey extensification & 2172 & 2099 & 1732 \\
\hline Grey intensification & 223 & 297 & 664 \\
\hline Green extensification & 1677 & 1637 & 1367 \\
\hline Green intensification & 183 & 224 & 493 \\
\hline
\end{tabular}

\section{Discussion}

\subsection{Urban Vegetation as A Globally Significant Ecosystem}

Globally, urban vegetation covers an area equivalent to the country of Belarus, and this area is rapidly increasing. Conservation and management of urban vegetation has received attention at the level of individual cities [58-60], but urban vegetation has not been mapped at a global scale for conservation monitoring purposes. Here, we show that urban vegetation covers a considerably greater area than some other ecosystems that have long been the focus of global conservation and monitoring efforts, such as mangrove forests [61]. Urban vegetation differs from natural ecosystem types in its heavy modification by people, high fragmentation [62], and dispersion across climatic zones and bioregions $[17,29]$. However, these factors have given rise to a novel variety of ecosystems that can support diverse biodiversity [63], and provide valuable services to urban residents [6,39]. While the total cover of urban vegetation is increasing worldwide, many individual green spaces have been lost due to urbanisation. Not all urban vegetation provides equal ecosystem services [9], and older patches may be disproportionately beneficial [64]. Urban vegetation warrants greater protection and restoration in future, due to its importance for people and urban biodiversity, its substantial area, and its rapid rate of change. Real-time or annual monitoring of urban vegetation cover could highlight areas of rapid vegetation loss to national and metropolitan governments, giving opportunities to take action and reduce unplanned spontaneous urban growth [65].

\subsection{Trajectories of Urban Vegetation Change}

Urban areas are subject to varied climatic, demographic, economic, and cultural pressures around the world [29], leading to a complex diversity of mechanisms that drive the observed trajectories of urban vegetation change. While the causes of change in individual cities require in-depth study, here we suggest some general mechanisms that may be common across urban areas. Urban vegetation cover declined in most urban areas between 2000 and 2015. The most common form of urban change was grey intensification; urban areas simultaneously grew larger and reduced in proportional vegetation cover. Grey extensification was common in developing regions that have rapidly urbanised. In many of the 10 countries with the greatest declines in green cover (Table 6), the percentage of the population classified as urban increased rapidly over the study period. For example, by $13 \%$ in Nigeria and 9\% in Vietnam [1]. Rapid urban growth in developing countries may drive suburban expansion and vegetation loss when governments have limited capacity to protect open spaces from informal settlement [33], and must prioritise more immediate sanitation, health, and economic concerns over providing and securing green space [33]. While a focus on such issues may bring short-term development gains, it can be difficult to re-create urban parks and gardens once they have been lost, thus depriving future urban residents of the ecosystem services provided by vegetation [38].

Few urban areas declined in size during the study period, but a substantial number grew only slightly (Figure 5; Table 7). Some urban areas have geographic or governance constraints that prevent suburban expansion [23]. In these areas, demand for land is likely to be high, leading to densification 
within the urban boundary and removal of existing urban green spaces. The UK provides an example of a country where urban vegetation cover has dramatically declined, while the size of urban areas has grown by a median of only 5\% (Table 7). Urban areas in the UK are subject to policies that strongly discourage suburban sprawl through the protection of greenbelt land, and encourage brownfield development [23]. Such brownfield development results in the loss of spontaneous vegetation cover on unused land [35], and higher pressure on inner-city land generally encourages denser urban forms that leave less amenity green space [36].

The majority of urban areas that increased in vegetation cover also increased in size (Figure 5; Table 7). One common mechanism behind this green extensification is low-density suburban sprawl, in which new peri-urban developments with high green cover act to "capture" peri-urban green space and increase the average cover across the urban area [66]. Urban sprawl can capture remnant patches of natural or semi-natural vegetation, which can support remaining biodiversity [67]. In other cases, urban sprawl has enveloped agricultural land, resulting in pockets of agricultural production across the suburban landscape that can provide substantial food. For example, 20\% of Mexico City's food production comes from within the urban boundary [68]. Finally, some green extensification has involved suburban expansion that has replaced rural vegetation with managed urban vegetation in a low-density matrix, typically in the form of private gardens [69].

A small number of urban areas increased in green cover while becoming smaller (Figure 5; Table 7 ). However, around $10 \%$ of urban areas increased in green cover while increasing in size by less than 5\% (Table 7). Green intensification was more common in regions with declining populations, such as Hungary, Serbia, and Romania (United Nations, 2018), or stagnant economies, such as the "rust belt" of North America [24]. As the demand for urban land declines, land abandonment can lead to spontaneous vegetation growth, causing an increase in green cover [35]. Urban vegetation cover can also increase alongside increases in population density, if there is strong protection for existing green spaces, and regulations or incentives that ensure that new urban developments make a net positive contribution to green cover [37]. For new developments, indicators such as the green plot ratio can be used to set quantitative green cover thresholds that developers must meet [70] Increases in vegetation cover can also be achieved through improving the management of private land parcels; for example through incentivising landowners to replace impervious cover in their gardens with vegetation [27].

\subsection{Implications of Global Changes in Vegetation Cover}

Reductions in urban vegetation cover are likely to reduce the provision of environmental, social, and economic benefits from urban vegetation, resulting in negative impacts such as elevated urban temperatures and flood risk [71,72]. The higher rate of loss of urban vegetation cover in Africa, Asia, and South America is therefore concerning, as these regions are particularly susceptible to environmental risks [73], and many urban residents depend more directly on ecosystem services for their livelihoods $[29,74]$.

If urban areas become greener in the future, they must choose to pursue either green extensification or green intensification. Future expansion of highly-vegetated suburbs could help to enhance the overall vegetation cover in a city, but would run the risk of negatively impacting surrounding rural ecosystems and their biodiversity or environmental assets such as carbon stocks [21,75]. Furthermore, suburban vegetation may not be equitably available to all urban residents [76]. Green intensification of existing urban areas could help to accommodate growing populations while adding new vegetated cover [36], but it is important to consider the types of vegetation that are added to a city, because different types of vegetation have different abilities to provide ecological functions and services [77]. For example, highly manicured parks and vegetated buildings may be added to increase the aesthetic value of dense cities during green intensification, but these vegetation types can have high associated maintenance costs $[78,79]$ and perform only a limited role in providing other ecosystem services such as supporting biodiversity $[80,81]$. 
High-rise construction and green building development requires technical expertise and can be expensive, requiring the transfer of knowledge and funding from cities that have successfully implemented these technologies [38]. To gain the most from urban vegetation, it is important to not only protect and increase the total vegetated area, but also to understand how best to manage these ecosystems to provide services to people [10]. Not all types of urban vegetation provide the same ecosystem services, and many existing urban parks and gardens are costly to maintain in terms of labour, water, and nutrient inputs [78]. The future design and management of urban vegetation must therefore balance the provision of services against the management costs [78].

\section{Conclusions}

The approach presented in this article may be repeated in the future to track continued changes in vegetation cover across the world's cities. Urban areas are expected to continue to grow and change rapidly over the next 50 years, putting pressure on existing urban vegetation and surrounding rural areas [21]. However, future urban development will also bring opportunities for urban greening, through new design innovations that make space for natural and semi-natural spaces [36], and new building typologies that increase the use of vegetation on top of living and working spaces [81]. To ensure that future cities support biodiversity and provide liveable green environments for people, urban vegetation requires more attention as a globally dispersed yet substantial ecosystem type.

Author Contributions: Conceptualization, D.R.R. and R.N.B.; methodology, D.R.R. and R.N.B.; formal analysis, D.R.R. and R.N.B.; writing-original draft preparation, D.R.R. and R.N.B.; writing—review and editing, D.R.R. and R.N.B. All authors have read and agreed to the published version of the manuscript.

Funding: The research was partially conducted at the Future Cities Laboratory at the Singapore-ETH Centre, which was established collaboratively between ETH Zurich and Singapore's National Research Foundation (FI 370074016) under its Campus for Research Excellence and Technological Enterprise programme.

Acknowledgments: We thank the editors and anonymous reviewers for their feedback which improved the article. We also thank the follow individuals for the use of their images, which were used under various Creative Commons licenses; Kenta Mabuchi, 2011 (Figure 1a), Pagodashophouse, Wikimedia, 2011 (Figure 1b), Pxhere, 2017 (Figure 1c), 20best.blogspot (Figure 1d), Geza Radics, 2012 (Figure 1e), Kreuzschnabel 2010 (Figure 1f).

Conflicts of Interest: The authors declare no conflict of interest.

\section{References}

1. United Nations. World Urbanization Prospects: The 2018 Revision. 2018. Available online: https://population. un.org/wup/ (accessed on 1 August 2019).

2. Elmqvist, T.; Setälä, H.; Handel, S.N.; van der Ploeg, S.; Aronson, J.; Blignaut, J.N.; Gómez-Baggethun, E.; Nowak, D.J.; Kronenberg, J.; De Groot, R. Benefits of restoring ecosystem services in urban areas. Curr. Opin. Environ. Sustain. 2015, 14, 101-108. [CrossRef]

3. Willis, K.J.; Petrokofsky, G. The natural capital of city trees. Science 2017, 356, 374-376. [CrossRef] [PubMed]

4. Beninde, J.; Veith, M.; Hochkirch, A. Biodiversity in cities needs space: A meta-analysis of factors determining intra-urban biodiversity variation. Ecol. Lett. 2015, 18, 581-592. [CrossRef] [PubMed]

5. Bolund, P.; Hunhammar, S. Ecosystem services in urban areas. Ecol. Econ. 1999, 29, 293-301. [CrossRef]

6. Hartig, T.; Kahn, P.H. Living in cities, naturally. Science 2016, 352, 938-940. [CrossRef]

7. Tzoulas, K.; Korpela, K.; Venn, S.; Yli-Pelkonen, V.; Kaźmierczak, A.; Niemela, J.; James, P. Promoting ecosystem and human health in urban areas using Green Infrastructure: A literature review. Landsc. Urban Plan. 2007, 81, 167-178. [CrossRef]

8. Lai, H.; Flies, E.J.; Weinstein, P.; Woodward, A. The impact of green space and biodiversity on health: Synthesis and systematic review. Front. Ecol. Environ. 2019. [CrossRef]

9. Zhang, Z.; Lv, Y.; Pan, H. Cooling and humidifying effect of plant communities in subtropical urban parks. Urban For. Urban Green. 2013, 12, 323-329. [CrossRef]

10. Gaston, K.J.; Ávila-Jiménez, M.L.; Edmondson, J.L. Managing urban ecosystems for goods and services. J. Appl. Ecol. 2013, 50, 830-840. [CrossRef] 
11. Dou, Y.; Zhen, L.; De Groot, R.; Du, B.; Yu, X. Assessing the importance of cultural ecosystem services in urban areas of Beijing municipality. Ecosyst. Serv. 2017, 24, 79-90. [CrossRef]

12. Chen, W.Y.; Wang, D.T. Economic development and natural amenity: An econometric analysis of urban green spaces in China. Urban For. Urban Green. 2013, 12, 435-442. [CrossRef]

13. Fuller, R.A.; Gaston, K.J. The scaling of green space coverage in European cities. Biol. Lett. 2009, 5, 352-355. [CrossRef] [PubMed]

14. Kabisch, N.; Haase, D. Green spaces of European cities revisited for 1990-2006. Landsc. Urban Plan. 2013, 110, 113-122. [CrossRef]

15. Richards, D.R.; Passy, P.; Oh, R.R.Y. Impacts of population density and wealth on the quantity and structure of urban green space in tropical Southeast Asia. Landsc. Urban Plan. 2017, 157, 553-560. [CrossRef]

16. Estoque, R.C.; Murayama, Y.; Myint, S.W. Effects of landscape composition and pattern on land surface temperature: An urban heat island study in the megacities of Southeast Asia. Sci. Total Environ. 2017, 577, 349-359. [CrossRef] [PubMed]

17. Huang, C.; Yang, J.; Lu, H.; Huang, H.; Yu, L. Green Spaces as an Indicator of Urban Health: Evaluating Its Changes in 28 Mega-Cities. Remote Sens. 2017, 9, 1266. [CrossRef]

18. Bagan, H.; Yamagata, Y. Land-cover change analysis in 50 global cities by using a combination of Landsat data and analysis of grid cells. Environ. Res. Lett. 2014, 9, 064015. [CrossRef]

19. Schneider, A.; Mertes, C.M.; Tatem, A.J.; Tan, B.; Sulla-Menashe, D.; Graves, S.J.; Patel, N.N.; Horton, J.A.; Gaughan, A.E.; Rollo, J.T.; et al. A new urban landscape in East-Southeast Asia, 2000-2010. Environ. Res. Lett. 2015, 10, 034002. [CrossRef]

20. Frolking, S.; Milliman, T.; Seto, K.C.; Friedl, M.A. A global fingerprint of macro-scale changes in urban structure from 1999 to 2009. Environ. Res. Lett. 2013, 8, 024004. [CrossRef]

21. Seto, K.C.; Güneralp, B.; Hutyra, L.R. Global forecasts of urban expansion to 2030 and direct impacts on biodiversity and carbon pools. Proc. Natl. Acad. Sci. USA 2012, 109, 16083-16088. [CrossRef]

22. Zhou, Y.; Varquez, A.C.G.; Kanda, M. High-resolution global urban growth projection based on multiple applications of the SLEUTH urban growth model. Sci. Data 2019, 6, 34. [CrossRef] [PubMed]

23. Dallimer, M.; Tang, Z.; Bibby, P.R.; Brindley, P.; Gaston, K.J.; Davies, Z.G. Temporal changes in greenspace in a highly urbanized region. Biol. Lett. 2011, 7, 763-766. [CrossRef] [PubMed]

24. Herrmann, D.L.; Schwarz, K.; Shuster, W.D.; Berland, A.; Chaffin, B.C.; Garmestani, A.S.; Hopton, M.E. Ecology for the Shrinking City. Bioscience 2016, 66, 965-973. [CrossRef]

25. Großmann, K.; Bontje, M.; Haase, A.; Mykhnenko, V. Shrinking cities: Notes for the further research agenda. Cities 2013, 35, 221-225. [CrossRef]

26. Endreny, T.A. Strategically growing the urban forest will improve our world. Nat. Commun. 2018, 9, 10-12. [CrossRef]

27. Cerra, J.F. Emerging strategies for voluntary urban ecological stewardship on private property. Landsc. Urban Plan. 2017, 157, 586-597. [CrossRef]

28. Oberndorfer, E.; Lundholm, J.; Bass, B.; Coffman, R.R.; Doshi, H.; Dunnett, N.; Gaffin, S.; Köhler, M.; Liu, K.K.Y.; Rowe, B. Green Roofs as Urban Ecosystems: Ecological Structures, Functions, and Services. Bioscience 2007, 57, 823. [CrossRef]

29. Richards, D.; Masoudi, M.; Oh, R.R.Y.; Yando, E.S.; Zhang, J.; Friess, D.A.; Grêt-Regamey, A.; Tan, P.Y.; Edwards, P.J. Global Variation in Climate, Human Development, and Population Density Has Implications for Urban Ecosystem Services. Sustainability 2019, 11, 6200. [CrossRef]

30. Manoli, G.; Fatichi, S.; Schläpfer, M.; Yu, K.; Crowther, T.W.; Meili, N.; Burlando, P.; Katul, G.G.; Bou-Zeid, E. Magnitude of urban heat islands largely explained by climate and population. Nature 2019, 573, 55-60. [CrossRef]

31. Artmann, M.; Inostroza, L.; Fan, P. Urban sprawl, compact urban development and green cities. How much do we know, how much do we agree? Ecol. Indic. 2019, 96, 3-9. [CrossRef]

32. Haase, D.; Kabisch, N.; Haase, A. Endless Urban Growth? On the Mismatch of Population, Household and Urban Land Area Growth and Its Effects on the Urban Debate. PLoS ONE 2013, 8, e66531. [CrossRef] [PubMed]

33. Du Toit, M.J.; Cilliers, S.S.; Dallimer, M.; Goddard, M.; Guenat, S.; Cornelius, S.F. Urban green infrastructure and ecosystem services in sub-Saharan Africa. Landsc. Urban Plan. 2018, 180, 249-261. [CrossRef] 
34. Badiu, D.L.; Onose, D.A.; Niță, M.R.; Lafortezza, R. From red to green? A look into the evolution of green spaces in a post-socialist city. Landsc. Urban Plan. 2019, 187, 156-164. [CrossRef]

35. Robinson, S.L.; Lundholm, J.T. Ecosystem services provided by urban spontaneous vegetation. Urban Ecosyst. 2012, 15, 545-557. [CrossRef]

36. Haaland, C.; Van Den Bosch, C.K. Challenges and strategies for urban green-space planning in cities undergoing densification: A review. Urban For. Urban Green. 2015, 14, 760-771. [CrossRef]

37. Monkkonen, P. Urban land-use regulations and housing markets in developing countries: Evidence from Indonesia on the importance of enforcement. Land Use Policy 2013, 34, 255-264. [CrossRef]

38. Jim, C. Green-space preservation and allocation for sustainable greening of compact cities. Cities 2004, 21, 311-320. [CrossRef]

39. Mcdonnell, M.J.; Macgregor-Fors, I. The ecological future of cities. Science 2016, 352, 936-938. [CrossRef]

40. Small, C.; Pozzi, F.; Elvidge, C.D. Spatial analysis of global urban extent from DMSP-OLS night lights. Remote Sens. Environ. 2005, 96, 277-291. [CrossRef]

41. Potere, D.; Schneider, A.; Angel, S.; Civco, D. Mapping urban areas on a global scale: Which of the eight maps now available is more accurate? Int. J. Remote Sens. 2009, 30, 6531-6558. [CrossRef]

42. Pesaresi, M.; Freire, S. GHS Settlement Grid Following the REGIO Model 2014 in Application to GHSL Landsat and Ciesin GPW v4-Multitemporal (1975-1990-2000-2015); Joint Research Centre; Available online: https: //data.europa.eu/euodp/data/dataset/jrc-ghsl-ghs_smod_pop_globe_r2016a (accessed on 1 August 2019).

43. Zhou, Y.; Smith, S.J.; Zhao, K.; Imhoff, M.; Thomson, A.; Bond-Lamberty, B.; Asrar, G.R.; Zhang, X.; He, C.; Elvidge, C.D. A global map of urban extent from nightlights. Environ. Res. Lett. 2015, 10, 054011. [CrossRef]

44. Wulder, M.A.; White, J.C.; Loveland, T.R.; Woodcock, C.E.; Belward, A.S.; Cohen, W.B.; Fosnight, E.A.; Shaw, J.; Masek, J.G.; Roy, D.P. The global Landsat archive: Status, consolidation, and direction. Remote Sens. Environ. 2016, 185, 271-283. [CrossRef]

45. Gorelick, N.; Hancher, M.; Dixon, M.; Ilyushchenko, S.; Thau, D.; Moore, R. Google Earth Engine: Planetary-scale geospatial analysis for everyone. Remote Sens. Environ. 2017, 202, 18-27. [CrossRef]

46. Zhu, Z.; Woodcock, C.E. Remote Sensing of Environment Object-based cloud and cloud shadow detection in Landsat imagery. Remote Sens. Environ. 2012, 118, 83-94. [CrossRef]

47. Azzari, G.; Lobell, D.B. Landsat-based classification in the cloud: An opportunity for a paradigm shift in land cover monitoring. Remote Sens. Environ. 2017, 202, 64-74. [CrossRef]

48. Xie, Y.; Lark, T.J.; Brown, J.F.; Gibbs, H.K. Mapping irrigated cropland extent across the conterminous United States at $30 \mathrm{~m}$ resolution using a semi-automatic training approach on Google Earth Engine. ISPRS J. Photogramm. Remote Sens. 2019, 155, 136-149. [CrossRef]

49. Ramoino, F.; Tutunaru, F.; Pera, F.; Arino, O. Ten-meter sentinel-2A cloud-free composite-Southern Africa 2016. Remote Sens. 2017, 9, 652. [CrossRef]

50. Pettorelli, N.; Ryan, S.; Mueller, T.; Bunnefeld, N.; Jedrzejewska, B.; Lima, M.; Kausrud, K. The Normalized Difference Vegetation Index (NDVI): Unforeseen successes in animal ecology. Clim. Res. 2011, 46, 15-27. [CrossRef]

51. Pericak, A.A.; Thomas, C.J.; Kroodsma, D.A.; Wasson, M.F.; Ross, M.R.V.; Clinton, N.E.; Campagna, D.J.; Franklin, Y.; Bernhardt, E.S.; Amos, J.F. Mapping the yearly extent of surface coal mining in central appalachia using landsat and google earth engine. PLOS ONE 2018, 13, e0197758. [CrossRef]

52. Johansen, K.; Phinn, S.; Taylor, M. Mapping woody vegetation clearing in Queensland, Australia from Landsat imagery using the Google Earth Engine. Remote Sens. Appl. Soc. Environ. 2015, 1, 36-49. [CrossRef]

53. Olson, D.M.; Dinerstein, E.; Wikramanayake, E.D.; Burgess, N.D.; Powell, G.V.N.; Underwood, E.C.; D'amico, J.A.; Itoua, I.; Strand, H.E.; Morrison, J.C.; et al. Terrestrial Ecoregions of the World: A New Map of Life on Earth. Bioscience 2001, 51, 933. [CrossRef]

54. Hansen, M.C.; Potapov, P.V.; Moore, R.; Hancher, M.; Turubanova, S.A.; Tyukavina, A.; Thau, D.; Stehman, S.; Goetz, S.; Loveland, T.; et al. High-resolution global maps of 21st-Century forest cover change. Science 2013, 342, 850-854. [CrossRef] [PubMed]

55. Olofsson, P.; Foody, G.M.; Herold, M.; Stehman, S.V.; Woodcock, C.E.; Wulder, M.A. Remote Sensing of Environment Good practices for estimating area and assessing accuracy of land change. Remote Sens. Environ. 2014, 148, 42-57. [CrossRef] 
56. Edgington, E.; Onghena, P. Randomization Tests; Chapman and Hall: London, UK, 2007.

57. Bates, D. Fitting linear mixed models in R. R News 2005, 5, 27-30.

58. Tan, P.Y.; Wang, J.; Sia, A. Perspectives on five decades of the urban greening of Singapore. Cities 2013, 32, 24-32. [CrossRef]

59. Caspersen, O.H.; Konijnendijk, C.C.; Olafsson, A.S. Green space planning and land use: An assessment of urban regional and green structure planning in Greater Copenhagen. Geogr. Tidsskr. 2006, 106, 7-20. [CrossRef]

60. Balooni, K.; Gangopadhyay, K.; Kumar, B.M. Governance for private green spaces in a growing Indian city. Landsc. Urban Plan. 2014, 123, 21-29. [CrossRef]

61. Hamilton, S.E.; Casey, D. Creation of a high spatio-temporal resolution global database of continuous mangrove forest cover for the 21st century (CGMFC-21). Glob. Ecol. Biogeogr. 2016, 25, 729-738. [CrossRef]

62. Andersson, E.; Barthel, S.; Borgström, S.; Colding, J.; Elmqvist, T.; Folke, C.; Gren, Å. Reconnecting cities to the biosphere: Stewardship of green infrastructure and urban ecosystem services. Ambio 2014, 43, 445-453. [CrossRef]

63. Aronson, M.F.J.; La Sorte, F.A.; Nilon, C.H.; Katti, M.; Goddard, M.A.; Lepczyk, C.A.; Warren, P.S.; Williams, N.S.G.; Cilliers, S.; Clarkson, B.; et al. A global analysis of the impacts of urbanization on bird and plant diversity reveals key anthropogenic drivers. Proc. R. Soc. B 2014, 281, 20133330. [CrossRef]

64. Ferraz, S.F.B.; Ferraz, K.M.; Cassiano, C.C.; Brancalion, P.H.S.; Da Luz, D.T.A.; Azevedo, T.N.; Tambosi, L.R.; Metzger, J.P. How good are tropical forest patches for ecosystem services provisioning? Landsc. Ecol. 2014, 29, 187-200. [CrossRef]

65. Schneider, A. Monitoring land cover change in urban and peri-urban areas using dense time stacks of Landsat satellite data and a data mining approach. Remote Sens. Environ. 2012, 124, 689-704. [CrossRef]

66. Xu, C.; Haase, D.; Pauleit, S. The impact of different urban dynamics on green space availability: A multiple scenario modeling approach for the region of Munich, Germany. Ecol. Indic. 2018, 93, 1-12. [CrossRef]

67. Canedoli, C.; Orioli, V.; Padoa-Schioppa, E.; Bani, L.; Dondina, O. Temporal variation of ecological factors affecting bird species richness in urban and peri-urban forests in a changing environment: A case study from Milan (Northern Italy). Forests 2017, 8, 507. [CrossRef]

68. Dieleman, H. Urban agriculture in Mexico City; balancing between ecological, economic, social and symbolic value. J. Clean. Prod. 2017, 163, S156-S163. [CrossRef]

69. Loram, A.; Tratalos, J.; Warren, P.H.; Gaston, K.J. Urban domestic gardens (X): The extent structure of the resource in five major cities. Landsc. Ecol. 2007, 22, 601-615. [CrossRef]

70. Lay Ong, B. Green plot ratio: An ecological measure for architecture and urban planning. Landsc. Urban Plan. 2003, 63, 197-211. [CrossRef]

71. Ziegler, A.D.; She, L.H.; Tantasarin, C.; Jachowski, N.R.; Wasson, R. Floods, false hope, and the future. Hydrol. Process. 2012, 26, 1748-1750. [CrossRef]

72. Roth, M. Review of urban climate research in (sub)tropical regions. Int. J. Climatol. 2007, 26, 1859-1873. [CrossRef]

73. Mora, C.; Dousset, B.; Caldwell, I.R.; Powell, F.E.; Geronimo, R.C.; Bielecki, C.R.; Counsell, C.W.W.; Dietrich, B.S.; Johnston, E.T.; Louis, L.V.; et al. Global risk of deadly heat. Nat. Clim. Chang. 2017, 7, 501-506. [CrossRef]

74. Vollmer, D.; Grêt-Regamey, A. Rivers as municipal infrastructure: Demand for environmental services in informal settlements along an Indonesian river. Glob. Environ. Chang. 2013, 23, 1542-1555. [CrossRef]

75. Radeloff, V.C.; Hammer, R.B.; Stewart, S.I. Sprawl and forest fragmentation in the U.S. Midwest from 1940 to 2000. Conserv. Biol. 2005, 19, 793-805. [CrossRef]

76. Ferguson, M.; Roberts, H.E.; McEachan, R.R.C.; Dallimer, M. Contrasting distributions of urban green infrastructure across social and ethno-racial groups. Landsc. Urban Plan. 2018, 175, 136-148. [CrossRef]

77. Vieira, J.; Matos, P.; Mexia, T.; Silva, P.; Lopes, N.; Freitas, C.; Correia, O.; Santos-Reis, M.; Branquinho, C.; Pinho, P. Green spaces are not all the same for the provision of air purification and climate regulation services: The case of urban parks. Environ. Res. 2018, 160, 306-313. [CrossRef] [PubMed]

78. Song, X.P.; Tan, P.Y.; Edwards, P.; Richards, D. The economic benefits and costs of trees in urban forest stewardship: A systematic review. Urban For. Urban Green. 2018, 29, 162-170. [CrossRef] 
79. Zhang, X.; Shen, L.; Tam, V.W.Y.; Lee, W.W.Y. Barriers to implement extensive green roof systems: A Hong Kong study. Renew. Sustain. Energy Rev. 2012, 16, 314-319. [CrossRef]

80. Wang, J.W.; Poh, C.H.; Tan, C.Y.T.; Lee, V.N.; Jain, A.; Webb, E.L. Building biodiversity: Drivers of bird and butterfly diversity on tropical urban roof gardens. Ecosphere 2017, 8, e01905. [CrossRef]

81. Belcher, R.N.; Sadanandan, K.R.; Goh, E.R.; Chan, J.Y.; Menz, S.; Schroepfer, T. Vegetation on and around large-scale buildings positively influences native tropical bird abundance and bird species richness. Urban Ecosyst. 2018, 22, 213-225. [CrossRef]

(C) 2019 by the authors. Licensee MDPI, Basel, Switzerland. This article is an open access article distributed under the terms and conditions of the Creative Commons Attribution (CC BY) license (http://creativecommons.org/licenses/by/4.0/). 